\title{
Sustainability analysis of transformable low-rise buildings production and construction integration zones
}

\author{
Alexander Pleshivcev ${ }^{1, *}$ \\ ${ }^{1}$ Moscow State University of Civil Engineering, Yaroslavskoe shosse, 26, Moscow, 129337, Russia
}

\begin{abstract}
One of the main issues of organizational and technological solutions progress of transformable low-rise buildings with sandwich panels walls (TLB) rapid construction is the improvement of industrial production methods based on the using of high-performance mechanization tools. The working capital efficiency improving makes pre-fabricated transformable buildings the most attractive technical solution for investor and allows you to quickly recoup investments. The traditional measures of the organization processes improvement and specific development directions of the TLB construction production organization in modern conditions are given. The technological component of sustainability has been highlighted. The specifics of its provision in the modern conditions of technical development and increasing innovation have been disclosed. The article defines the prerequisites for main components strengthening of the integration zones elements sustainability in the process of transformable low-rise buildings erection. The tendencies of sustainability concept expanding at different levels of the TLB construction production management are substantiated. Evaluation of its effectiveness determines the relevance of the study. The aim of the work is the development of scientific and methodological foundations for the formation of a regional strategy for prefabricated low-rise construction.
\end{abstract}

\section{Introduction}

Construction, like any other branch of material production, is based on the next principles $[1,9,11]$ :

- movement or immobility of the technological cycle elements are relative to each other at any time (period);

- different duration of technological cycles;

- the variety of operation combinations in space and in time;

- the technological cycle dynamism and flexibility;

- the number of staff sufficiency and its qualification.

At various stages of the construction development science and production the construction time reducing task was solved by a rational combination of new constructivetechnological and organizational solutions. The problem of construction technologies

*Corresponding author: perspektiva-aa@mail.ru 
development to make a low-cost buildings erection in the shortest time was particularly acute in Russia during the period of intensive development of new country areas, with new workers' settlements constructions $[6,7]$.

The various purposes low-rise buildings erection technology in mass modern construction are determined by its technological and space-planning decisions, functional purpose, construction conditions and requirements for building energy saving [10, 13, 14$]$.

In modern construction practice the common TLB construction technologies, as a rule, involve mainly manual labor usage and are distinguished by increased labor-intensiveness and duration, which lead together to construction time and investment returning time increasing [2].

At the present time, the low-rise building erection technology is developing in the direction of construction time reducing. The labor costs ratio between in factory and construction site scope of work is changing in the direction of site works reduction. The fast-built technology means a significant construction labor costs reduction in comparison with the factory works scope [12].

Based on the experience of modern prefabricated low-rise buildings erection, the tasks of its improvement are aimed at competitive indicators of manufacturability providing [3].

According to the scientific and technical level this solution means the development of a new pre-fabricated building models based on the results of scientific researches, surpassing the advanced Russian and foreign models [4].

Pre-fabricated building constructive-technological solutions quality level means the degree of compliance with the construction organization and technology regulatory requirements; the level of competitiveness of pre-fabricated buildings is determined by the degree of its innovative projects demand; the level of pre-fabricated buildings manufacturability is determined by indicators of labor intensity, construction duration and cost, comparable with traditional technologies $[5,8]$.

In accordance with the specified parameters, one of the most promising solutions is the transformable low-rise building (TLB) development. TLB transportation is performed with flat packages. Due to the design of nodal connections, it can be easily transformed in design position. During erection process fastening elements and spatial fixation are performed with prefabricated units. Communication engineering inputs fastened with quick-assembly devices, and external seams are sealed with durable materials.

The decision of fast-built low-rise building packages transportation is determined by the movement rationality, as well as loading and unloading operations implementation, matching the overall building dimensions with an existing fleet of specialized vehicles. In package sets supply of folding, transforming pre-fabricated building, provides installation equipment, inventory, a building passport, component equipment documents.

In this way, according to basic regulatory and technical documentation requirements, the improvement of low-rise building construction technologies can be implemented by developing a TLB with a high degree of industrialization.

At the first stage it is necessary to organize the production of transformable prefabricated low-rise buildings with sandwich panels. It is possible due to the reconstruction of existing woodworking enterprises and, above all, GWS plants (glued wooden structures), as well as enterprises producing sandwich panels.

At the second stage, the problem of building elements rational transportation like an easily foldable compact package and transportation costs reduction due to its simultaneous several packages transportation.

For most pre-fabricated buildings, traditional machinery and equipment are in use. So, using an industrial elements and structures with a high degree of node connection elements assembly can significantly reduce construction site works and positively affect the finished building quality. 
However, the integration of new constructive-technological solutions in mass prefabricated low-rise building constructions is hampered in Russia for lack of a regulatory framework, organizational and technical re-equipment difficulties and re-profiling of obsolete factories complexity.

The rapid building construction is characterized by a mechanical model of organization, with clearly defined connections, functions, labor divisions, which are overall acting as a single mechanism for the result achieving.

In specific conditions the production program process formation, the volume of construction and installation works may vary in sufficiently large limits.

Construction entrepreneurship always carries with the risk of a construction organization inconsistent (in terms of its organizational, technological, economic and innovative condition), with a mismatch of the process structure and installation works planned volume for a certain period. As soon as compliance in one of the indicated conditions is violated, the arising risk can cause the construction organization insolvency and lead it to bankruptcy. Therefore, a systematic analysis of organizational, technological, economic and innovative inconsistencies is needed at the effective production program stage formation.

\section{Materials and methods}

Three organizational and technological production system states were identified, and rational zones of factor groups influences on economic indicators were determined for analysis $[15,16]$ :

- the rational zone of TLB material consumption influence on the cost price (physical, chemical and mechanical material properties factors), (fig.1);

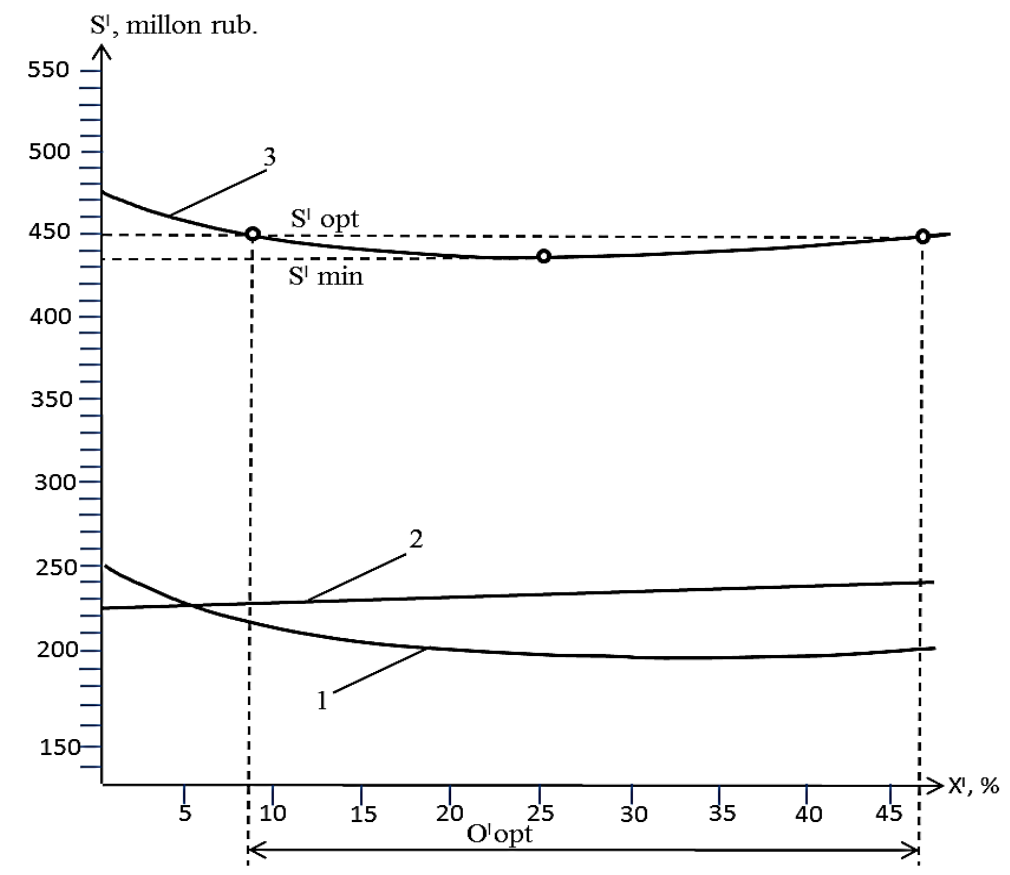

Fig. 1. TLB production cost changing rational zone determination (material consumption parameter):

1) Price change depending on TLB enclosing structures physical and chemical material properties;

2) Price change depending on mechanical properties of materials; 3) Summing curve. 
- the rational zone of mechanization and specialization levels in the TLB flexible technology production influence on the cost, (fig.2);

- the rational zone of TLB degree concentration at construction site influence on the cost (for example, it was found that with the minimization of TLB erection cost, the optimal quantity of the basic modules at construction site are 5-15 pcs), (fig.3).

Combined methods: mathematical and statistical methods based on measurable indicators and statistical modeling, based on expert assessments. Research methods allowed TLB production enterprises ranking to determine potential opportunities of innovative development level. The motivation for the factories can serve:

- TLB demand increasing, which will provide benefits and create new opportunities for facilities;

- increase competitiveness;

- need for modernization, new equipment opens up opportunities for TLB quality characteristics improvement;

- products (services) quality improving within production technologies enhancement.

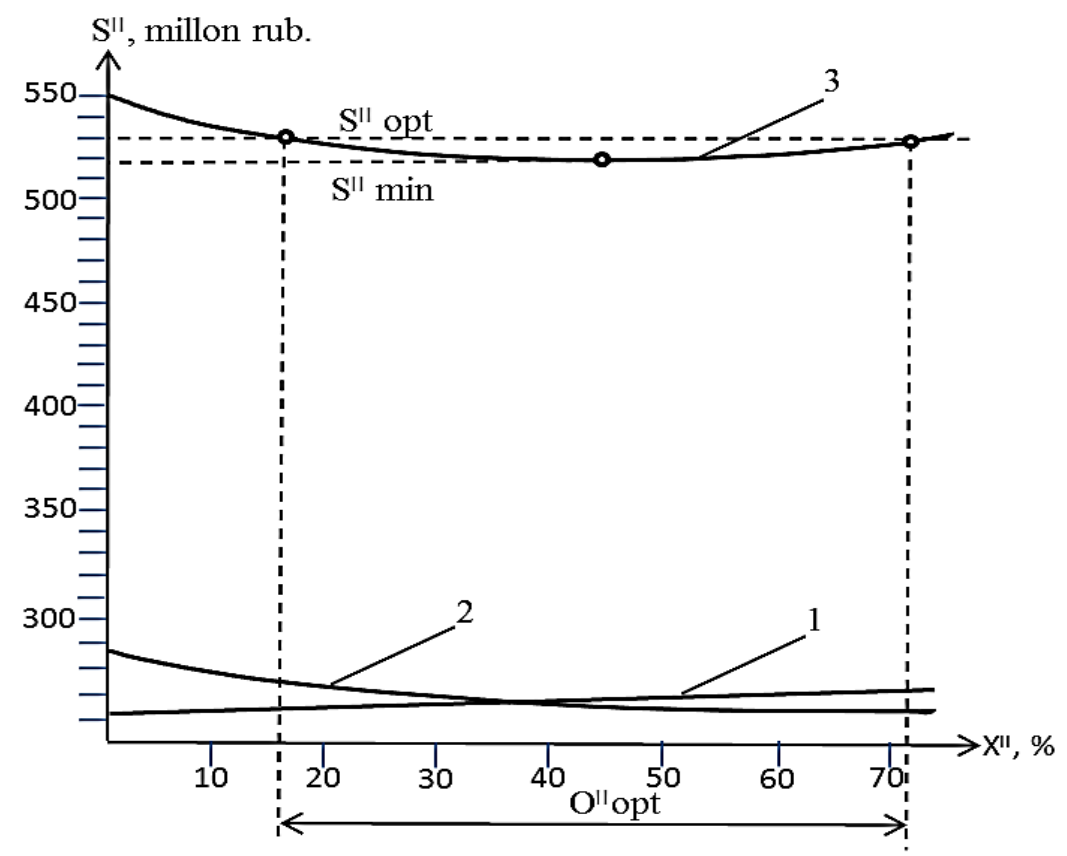

Fig. 2. TLB production cost changing rational zone determination (mechanization and specialization parameters): 1) Price change depending on mechanization level of the factory and its specialization; 2) Price change depending on investments in technical progress; 3) Summing curve. 


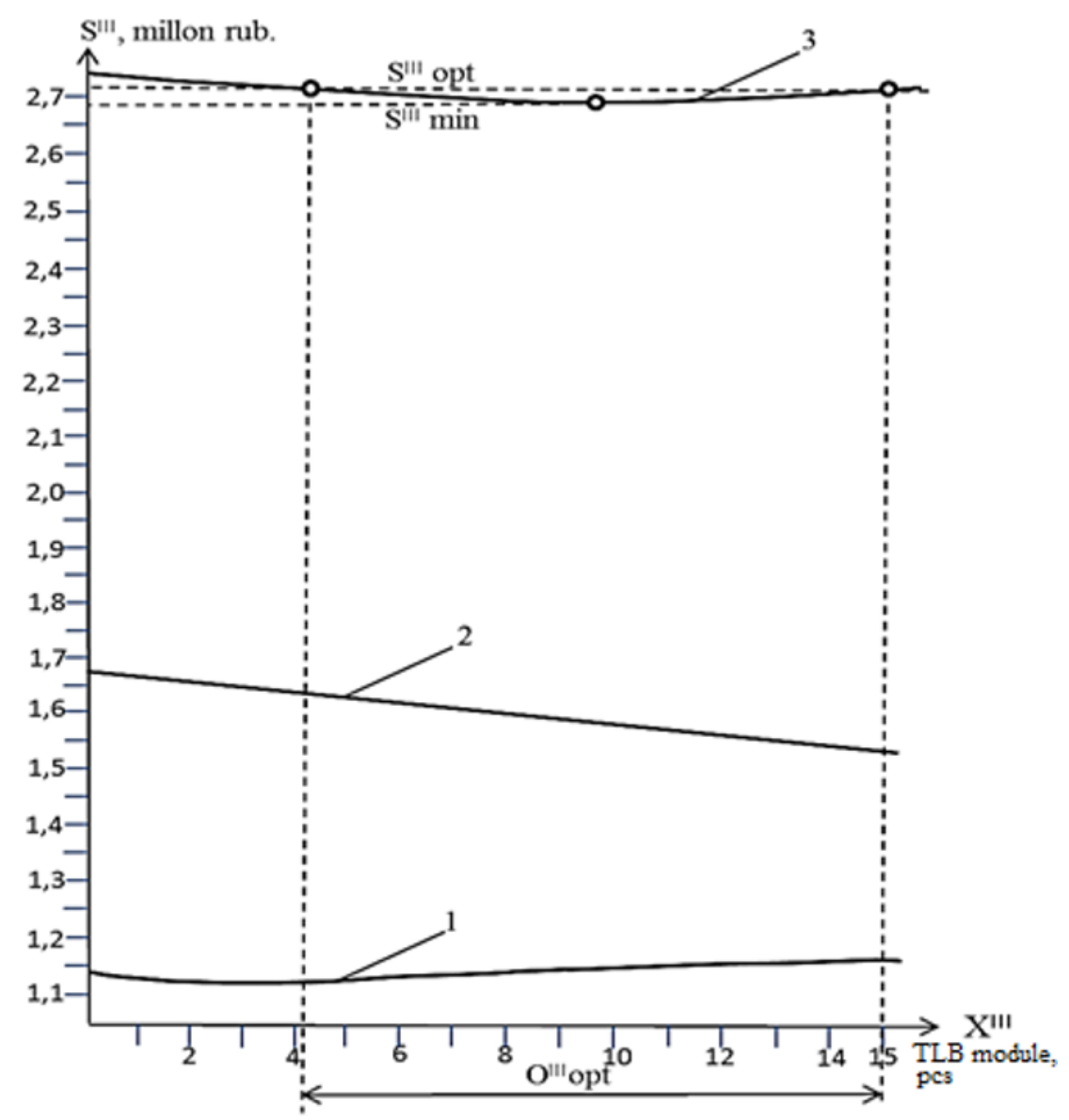

Fig. 3. TLB production cost changing rational zone determination (buildings degree concentration at construction site): 1) Price change depending on TLB erection cost; 2) Price change depending on construction master plan buildings utilization; 3) Summing curve.

The above study results show that the establishment of rational usage areas of the construction enterprise possibilities for different organizational and technological conditions may not fully or partially coincide with each other.

The indicator is the development of a new TLB products in the methodology of statistics - the volume of goods, work, services, both new and old one which have been changed over the years.

The method of integral indicator calculation of the TLB factory development, which is based on calculated by years and standardized indicators, will be able to characterize the development, reflect the production flexibility, scientific, technical, social and economic effect of TLB production implementation.

\section{Results}

The creation and operation effectiveness of the construction enterprise economic and organizational system depends of usage degree not only in terms of nominal value, but also in ensuring the combination of its organizational, economic and innovation sustainability. For the formation of organizational system technical and economic assessments. It is necessary to have the appropriate methodological foundations, which at the stages of 
technical preparation, process operations, situations forecasting during work planning and bidding, to have predicted values of TLB target construction production minimum cost and permissible changes in its organizational, economic and innovative parameters.

For TLB production system main environmental factors are:

- population's necessity in such type of inventories;

- market saturation with TLB offers;

- competitiveness (price, design) of the proposed TLB;

- materials availability in markets with the necessary physical, chemical and quality characteristics;

- the construction industry facilities technological capabilities TLB production;

- availability of lifting and transport equipment and machinery for transportation and installation.

The system of rapid TLB construction is based on next main organizational and technological principles:

a) life cycle of the TLB system (one of the stages is installation - one basic (100 m2) TLB module can be mounted in 8.8 hours);

b) the system transformability:

- the building transformability due to its constructive and technological solution (basic TLB module has 8 transformation nodes);

- development transformability - using of various planning solutions both for building and area around it, which increases construction works concentration (for example, the number of TLB at site is up to 15 pieces with in an optimal cost);

c) the evolutionarily changeable TLB production industrialization, including the specialization of products along technological lines ( 2 products are assigned to the line).

\section{Discussion}

The method of economic and organizational-technological sustainability calculation of the TLB system production includes the following steps:

- the allocation of individual organizational and technological states of the system.

Three states were considered (reflecting: physical, chemical and mechanical properties of materials and products; TLB prefabrication process state with the flexible technology; at site TLB installation condition):

- groups of organizational, technological and economic factors identification affecting the stability of each TLB production system states;

- determination of rational zones of organizational and technological factors groups influence on the cost of inventories. In this way, the influence rational zones were determined: the base TLB module material consumption; the level of mechanization and specialization during the base module production; houses degree of concentration at construction site;

- integral assessment of TLB production process based on the developed multifactor three-plane sustainable development model. The model is based on finding the integral area of organizational and technological factors rational zones influence and combining it in various states of the process. The integral scope corresponds each zone optimal costs.

On the basis of the developed methodology it was found that the least costly way of TLB production organization is to re-equip the low-margin existing woodworking plants. In these enterprises are necessary to place a sandwich panels line and a TLB prefabrication section. It requires $300-400 \mathrm{~m} 2$, which is possible with the existing large areas of storage space partial release. 


\section{Conclusion}

Studies have confirmed the assumption that it is necessary to create the prerequisites for sustainable (organizational, economic, innovative) development of a construction company in order to achieve the desired results (TLB production sales volume, profit, efficiency).

It is shown that the degree of deviation from the trajectory of sustainable development can be characterized by the level of the construction enterprise limiting possibilities usage, which is changing under the influence of its external and internal environment factors under the conditions of divergent trends in its components over time. The first component should be considered as a production organization, which parameters should correspond as much as possible to specified TLB production characteristics and its volumes. The second component is aimed at sustainable development of the full-assembly TLB production with a flexible technology. The third component ensures the sustainability of the ultimate organizational installation capabilities of TLB construction. In addition, each of the components acts both positive and negative effects. Consequently, the construction company at the stage of TLB production technological preparation and construction productivity can use methods which establish, analyze and ensure an equilibrium state of sustainable development with minimal costs.

\section{References}

1. E.A. Korol, S.V. Komissarov, P.B. Kagan, S.G. Arutiunov, Promyshlennoe i grazhdanskoe stroitel'stvo 3, 43 (2011)

2. E.A. Korol, A.A. Pleshivtsev, Tekhnologiya vozvedeniya transformiruemykh maloetazhnykh zdanii iz sendvich-panelei, dis. k.t.n (2017)

3. I.Kh. Nanazashvili, A.A. Pleshivtsev, Stroitel'nye materialy oborudovanie tekhnologii XXI veka 2 (2011)

4. M.S. Nikol'skii, Yu.N. Kazakov, Vestnik grazhdanskikh inzhenerov 2, 99 (2011)

5. M.S. Nikol'skii, Modelirovanie ratsional'nykh tekhnologicheskikh reshenii dlya snizheniya trudoemkosti i stoimosti na osnove mnogokriterial'noi optimizatsii, Proc. of Conf. Upravlenie stroitel'stvom v sovremennykh usloviyakh (2009)

6. A.A. Pleshivtsev, Gradostroitel'stvo 6, 66 (2013)

7. A.A. Pleshivtsev Bazovoe ponyatie sistemnogo podkhoda pri otsenke proizvodstva i vozvedeniya transformiruemykh bystrovozvodimykh maloetazhnykh zhilykh zdanii, Proc. of the Conf.Aktual'nye voprosy tekhnicheskikh nauk» (2014)

8. A.A. Pleshivtsev, Gradostroitel'stvo 3, 90 (2014)

9. B.V. Prykin, Tekhniko-ekonomicheskii analiz proizvodstva (YuNITI-DANA, 2003)

10. V.S. Semenov, A.M. Grekhovodov, A.V. Kondrashov, Vestnik KyrgyzskoRossiiskogo slavyanskogo universiteta 9, 154 (2008)

11. B.S. Strigin, Sbornik nauchnykh trudov VGASU (2009)

12. T.A. Suetina T.A., I.Kh. Nanazashvili, A.A. Pleshivtsev, Vestnik VolgGASU Stroitel'stvo i arkhitektura $\mathbf{5 0}$ (2013)

13. S.A. Sychev, Inzhenernyi vestnik Dona 4, 65 (2015)

14. N.S. Tikhonova, G.A. Svishchev, O.I. Sedlyarov, Dizain i tekhnologii 39, 61 (2014)

15. V.O. Chulkov, Mnogourovnevoe infograficheskoe modelirovanie: Modul'nyi kurs lektsii (Infografiya, 2007)

16. V.O. Chulkov, P.P. Kazaryan, Promyshlennoe i grazhdanskoe stroitel'stvo 2, 58 (2009) 